\title{
" MENINGKATKAN AKTIFITAS BELAJAR PAI MATERI IBADAH PUASA RAMADHAN MELALUI PEMBELAJARAN KOOPERATIF BERBANTUAN MEDIA GAMBAR PADA PESERTA DIDIK KELAS V DI SDN I SUNGAI KAPITAN TAHUN PELAJARAN 2019/2020"
}

\author{
Oleh : \\ Muhamad Junaidi \\ *SDN I Sungai Kapitan
}

\begin{abstract}
Abstrak
Mengajarkan puasa kepada anak mungkin susah-susah gampang, kadang ada anak yang ingin sekali puasa bersama anggota keluarga lainnya. Ada pula yang tidak ingin, salah satu materi yang di pelajari di kelas $V$ adalah ibadah puasa ramadhan, puasa ramadhan menurut syariat Islam adalah suatu amalan ibadah yang dilakukan dengan menahan diri dari segala sesuatu seperti makan, minum, perbuatan buruk maupun dari yang membatalkan puasa mulai dari terbitnya fajar hingga terbenamnya matahari yang disertai dengan niat karena Allah SWT, dengan syarat dan rukun tertentu. Jadi melaksanakan puasa Ramadhan adalah wajib hukumnya, di mana hal tersebut adalah bentuk pertanggungjawaban manusia kepada penciptanya secara langsung serta kegiatan yang menyangkut hablum minallah. Bulan suci Ramadhan merupakan kesempatan bagi setiap hamba Allah untuk lebih meningkatkan ketakwaan, dikarenakan bulan ini memiliki beberapa keutamaan atau manfaat. Selanjutnya guru melakukan wawancara terhadap beberapa siswa, yang hasilnya adalah siswa jenuh dan merasa bosan dengan pembelajaran di kelas. Dari hasil wawancara itulah, guru berinisiatif menggunakan model pembelajaran yang tidak biasa di pakai di kelas, yakni menggunakan pembelajaran kooperatif berbantuan media gambar. Metode pembelajaran kooperatif merupakan metode pembelajaran dengan kelompok kecil siswa dan membangun kondisi belajar yang kondusif. Sedangkan media gambar adalah segala sesuatu yang diwujudkan secara visual kedalam bentuk dua dimensi sebagai curahan ataupun pikiran yang bentuknya bermacam-macam seperti lukisan, potret, slide, film, strip, opaque projektor. "Meningkatkan Aktifitas belajar PAI Materi Ibadah Puasa Ramadhan Melalui Pembelajaran Kooperatif Berbantuan Media Gambar Pada Peserta Didik Kelas V di SDN I Sungai Kapitan Tahun Pelajaran 2019/2020"
\end{abstract}

\begin{abstract}
Teaching fasting to children may be difficult, sometimes there are children who really want to fast with other family members. There are also those who do not want to, one of the materials learned in grade $V$ is the fasting of Ramadan, Ramadan fasting according to Islamic law is a practice of worship which is done by refraining from everything such as eating, drinking, bad deeds or from breaking the fast. from the rising of the dawn to the setting of the sun which is accompanied by the intention of Allah SWT, with certain conditions and pillars. So carrying out the fasting of Ramadan is obligatory, where it is a form of direct human responsibility to its creator as well as activities related to the minimum habit. The holy month of Ramadan is an opportunity for every servant of Allah to further increase his piety, because this month has several virtues or benefits. Furthermore, the teacher conducted interviews with several students, the result was that the students were bored and bored with learning in class. From the results of the interview, the teacher took the initiative to use a learning model that was not usually used in the classroom, namely using picture-assisted cooperative learning. Cooperative learning method is a learning method with small groups of students and builds conducive learning conditions. Meanwhile, image media is anything that is manifested visually into a two-dimensional form as an outpouring or thought in various forms such as paintings, portraits, slides, films, strips, and opaque projectors. "Increasing PAl learning activities for Ramadan fasting material through cooperative learning assisted by image media for fifth grade students at SDN I Sungai Kapitan for the 2019/2020 academic year"
\end{abstract}

\section{PENDAHULUAN}

Mengajarkan puasa kepada anak mungkin susahsusah gampang, kadang ada anak yang ingin sekali puasa bersama anggota keluarga lainnya. Ada pula yang tidak ingin, sebelum mengajari anak puasa, sebaiknya beri pengertian kepada anak terlebih dahulu apa itu puasa dan mengapa mereka perlu menjalankannya tiap tahun. Setelah itu, anak mungkin akan lebih mudah untuk mengikuti ibadah puasa.
Salah satu materi yang di pelajari di kelas $\mathrm{V}$ adalah ibadah puasa ramadhan, puasa ramadhan menurut syariat Islam adalah suatu amalan ibadah yang dilakukan dengan menahan diri dari segala sesuatu seperti makan, minum, perbuatan buruk maupun dari yang membatalkan puasa mulai dari terbitnya fajar hingga terbenamnya matahari yang disertai dengan niat karena Allah SWT, dengan syarat dan rukun tertentu. Jadi melaksanakan puasa Ramadhan adalah wajib 
hukumnya, di mana hal tersebut adalah bentuk pertanggungjawaban manusia kepada penciptanya secara langsung serta kegiatan yang menyangkut hablum minallah. Bulan suci Ramadhan merupakan kesempatan bagi setiap hamba Allah untuk lebih meningkatkan ketakwaan, dikarenakan bulan ini memiliki beberapa keutamaan atau manfaat.

Oleh karenanya disini, guru menganggap permasalahan aktifitas belajar siswa perlu di tingkatkan, karenanya jika di biarkan maka nilai siswa tidak akan mengalami kemajuan. Selanjutnya guru melakukan wawancara terhadap beberapa siswa, yang hasilnya adalah siswa jenuh dan merasa bosan dengan pembelajaran di kelas. Dari hasil wawancara itulah, guru berinisiatif menggunakan model pembelajaran yang tidak biasa di pakai di kelas, yakni menggunakan pembelajaran kooperatif berbantuan media gambar. Metode pembelajaran kooperatif merupakan metode pembelajaran dengan kelompok kecil siswa dan membangun kondisi belajar yang kondusif. Sedangkan media gambar adalah segala sesuatu yang diwujudkan secara visual kedalam bentuk dua dimensi sebagai curahan ataupun pikiran yang bentuknya bermacammacam seperti lukisan, potret, slide, film, strip, opaque projektor.

Berdasarkan latar belakang masalah di atas, peneliti hendak melakukan penelitian dengan judul "Meningkatkan Aktifitas belajar PAl Materi Ibadah Puasa Ramadhan Melalui Pembelajaran Kooperatif Berbantuan Media Gambar Pada Peserta Didik Kelas V di SDN I Sungai Kapitan Tahun Pelajaran 2019/2020"

\section{KAJIAN TEORI}

\section{A. Aktifitas Belajar Siswa}

\section{Pengertian Aktifitas belajar}

Pembelajaran yang efektif adalah pembelajaran yang menyediakan kesempatan belajar sendiri atau melakukan aktivitas sendiri. Proses pembelajaran yang dilakukan di dalam kelas merupakan aktivitas mentransformasikan pengetahuan, sikap, dan ketrampilan (Martinis Yamin, 2007: 75). Aktivitas merupakan prinsip atau asas yang sangat penting dalam interaksi belajar mengajar (Sardiman, 2006: 96).

Saat pembelajaran belangsung siswa mampu memberikan umpan balik terhadap guru. Sardiman (2006: 100) menyatakan bahwa aktivitas belajar merupakan aktivitas yang bersifat fisik maupun mental. Dalam kegiatan belajar keduanya saling berkaitan. Oemar Hamalik (2009: 179) menyatakan bahwa aktivitas belajar merupakan kegiatan yang dilakukan oleh siswa dalam kegiatan pembelajaran.

\section{Jenis-jenis Aktivitas}

Menurut Sardiman (2006: 100), aktivitas belajar meliputi aktivitas yang bersifat fisik maupun mental. Dalam kegiatan belajar kedua aktivitas tersebut harus selalu berkait. Aktivitas belajar siswa sangat kompleks. Paul B. Diedrich (Sardiman, 2006: 101), menyatakan bahwa kegiatan siswa digolongkan sebagai berikut:
I) Visual activities, diantaranya meliputi membaca, memperhatikan gambar demonstrasi, percobaan

2) Oral activities, seperti menyatakan, merumuskan, bertanya, memberi saran, dan mengeluarkan pendapat

3) Listening activities, seperti misalnya mendengarkan percakapan, diskusi dan pidato.

4) Writing activities, misalnya menulis cerita, karangan, laporan dan menyalin.

5) Motor activities, misalnya melakukan percobaan, membuat konstruksi, model mereparasi, bermain, berkebun, beternak;

6) Mental activities, misalnya menanggapi, mengingat, memecahkan soal, dan menganalisis.

7) Emotional activities, misalnya, menaruh minat, merasa bosan, gembira, bersemangat, bergairah, berani, tenang, gugup.

\section{B. Pembelajaran Kooperatif Berbantuan Media Gambar}

I) Pembelajaran Kooperatif

I. Pengertian Pembelajaran Kooperatif

Adalah pendekatan pembelajaran yang berfokus pada penggunaan kelompok kecil siswa untuk bekerja sama dalam memaksimalkan kondisi belajar untuk mencapai tujuan belajar.

\section{Konsep Dasar Pembelajaran}

\section{Kooperatif}

Pada dasarnya manusia mempunyai perbedaan, dengan perbedaan itu manusia saling asah, asih, asuh ( saling mencerdaskan ). Dengan pembelajaran kooperatif diharapkan saling menciptakan interaksi yang asah, asih, asuh sehingga tercipta masyarakat belajar ( learning community ). Siswa tidak hanya terpaku belajar pada guru, tetapi dengan sesama siswa juga.

Pembelajaran kooperatif adalah pembelajaran yang secara sadar dan sengaja mengembangkan interaksi yang silih asuh untuk menghindari ketersinggungan dan kesalahpahaman yang dapat menimbulkan permusuhan, sebagai latihan hidup di masyarakat.

\section{Ciri-Ciri Pembelajaran Kooperatif}

Didalam pembelajaran kooperatif terdapat elemen-elemen yang berkaitan. Menurut Lie ( 2004 ):

I). Saling ketergantungan positif

Dalam pembelajaran kooperatif, guru menciptakan suasana yang mendorong agar siswa merasa saling membutuhkan atau yang biasa disebut dengan saling ketergantungan positif yang dapat dicapai melalui : saling ketergantungan mencapai tujuan, saling ketergantungan menyelesaikan tugas, saling ketergantungan bahan atau sumber, saling ketergantungan peran, saling ketergantungan hadiah.

2). Interaksi tatap muka

Dengan hal ini dapat memaksa siswa saling bertatap muka sehingga mereka akan berdialog. Dialog tidak hanya dilakukan dengan guru tetapi dengan teman sebaya juga karena biasanya siswa akan lebih luwes, lebih mudah belajarnya dengan teman sebaya. 


\section{3). Akuntabilitas individual}

Pembelajaran kooperatif menampilkan wujudnya dalam belajar kelompok. Penilaian ditunjukkan untuk mengetahui penguasaan siswa terhadap materi pelajaran secara individual. Hasil penilaian ini selanjutnya disampaikan oleh guru kepada kelompok agar semua kelompok mengetahui siapa kelompok yang memerlukan bantuan dan siapa yang dapat memberikan bantuan,maksudnya yang dapat mengajarkan kepada temannya. Nilai kelompok tersebut harus didasarkan pada rata-rata, karena itu anggota kelompok harus memberikan kontribusi untuk kelompnya. Intinya yang dimaksud dengan akuntabilitas individual adalah penilaian kelompok yang didasarkan pada rata-rata penguasaan semua anggota secara individual.

\section{Unsur - Unsur Model Pembelajaran Kooperatif}

Menurut Roger dan David Johnson ada 5 unsur dalam model pembelajaran kooperatif, yaitu :

I). Positive interdependence ( saling ketergangtungan positif )

Unsur ini menunjukkan bahwa dalam pembelajaran kooperatif ada 2 pertanggungjawaban kelompok. Pertama, mempelajari bahan yang ditugaskan kepada kelompok. Kedua, menjamin semua anggota kelompok secara individu mempelajari bahan yang ditugaskan tersebut.

Beberapa cara membangun saling ketergantungan positif yaitu :

a) Menumbuhkan perasaan peserta didik bahwa dirinya terintegrasi dalam kelompok, pencapaian tujuan terjadi jika semua anggota kelompok mencapai tujuan.

b) Mengusahakan agar semua anggota kelompok mendapatkan penghargaan yang sama jika kelompok mereka berhasil mencapai tujuan.

c) Mengatur sedemikian rupa sehingga setiap peserta didik dalam kelompok hanya mendapatkan sebagian dari keseluruhan tugas kelompok.

d) Setiap peserta didik ditugasi dengan tugas atau peran yang saling mendukung dan saling berhubungan, saling melengkapi dan saling terikat dengan peserta didik lain dalam kelompok.

\section{2) Media Gambar}

\section{Pengertian Media Gambar}

Di antara media pembelajaran, media gambar adalah media yang palingumum dipakai. Hal ini dikarenakan siswa lebih menyukai gambar daripada tulisan, apalagi jika gambarnya dibuat dan disajikan sesuai dengan persyaratan gambar yang baik, sudah barang tentu akan menambah semangat siswa dalam mengikuti proses pembelajaran.

Media gambar adalah segala sesuatu yang diwujudkan secara visual kedalam bentuk dua dimensi sebagai curahan ataupun pikiran yang bentuknya bermacam-macam seperti lukisan, potret, slide, film, strip, opaque projektor.

Media gambar adalah media yang paling umum dipakai, yang merupakan bahasan umum yang dapat dimengerti dan dinikmati dimana-mana. Media gambar merupakan peniruan dari benda-benda dan pemandangan dalam hal bentuk, rupa, serta ukurannya relatif terhadap lingkungan.

Dari pengertian di atas dapat disimpulkan bahwa media gambar adalah perwujudan lambang dari hasil peniruan-peniruan benda-benda, pemandangan, curahan pikir atau ide-ide yang divisualisasikan kedalam bentuk dua dimensi. Bentuknya dapat berupa gambar situasi dan lukisan yang berhubungan dengan pokok bahasan.

\section{Fungsi Media Gambar}

Pemanfaatan media pembelajaran ada dalam komponen metode mengajar sebagai salah satu upaya untuk mempertinggi proses interaksi guru-siswa dan interaksi siswa dengan lingkungan belajarnya. Oleh sebab itu fungsi utama dari media pembelajaran adalah sebagai alat bantu mengajar, yakni menunjang penggunaan metode mengajar yang dipergunakan guru.

3. Kelebihan dan Kelemahan Media Gambar

I) Kelebihan Media Gambar

Adapun kelebihan dari media gambar adalah sebagai berikut.

a) Sifatnya konkrit dan lebih realistis dalam memunculkan pokok masalah, jikadibandingkan dengan bahasa verbal.

b) Dapat mengatasi batasan ruang dan waktu. kita.

c) Dapat mengatasi keterbatasan pengamatan

d) Memperjelas masalah dalam bidang apa saja dan untuk semua orang tanpa memandang umur sehingga dapat mencegah atau membetulkan kesalahpahaman. digunakan

e) Harganya murah dan mudah didapat serta

2) Kelemahan Media Gambar

Selain kelebihan yang dimiliki, media gambar memiliki kelemahan, diantaranya sebagai berikut.

a) Hanya menampilkan persepsi indera mata, ukurannya terbatas hanya dapat terlihat oleh sekelompok siswa. subyektif.

b) Gambar diintepretasikan secara personal dan

c) Gambar disajikan dalam ukuran yang sangat kecil, sehingga kurang efektif dalam pembelajaran.

\section{METODE PENELITIAN}

\section{A. Setting Penelitian}

\section{Tempat Penelitian}

Penelitian tindakan kelas ini dilakukan di SDN I

Sungai Kapitan dengan profile sebagai berikut:

NPSN : 30201824

Status : Negeri

Bentuk Pendidikan : SD

Status Kepemilikan : Pemerintah Daerah

SK Pendirian Sekolah : 539 Tahun 2017

Tanggal SK Pendirian : 2017-08-0।

SK Izin Operasional : 539 Tahun 2017

Tanggal SK Izin Operasional : 2017-08-0I

Kebutuhan Khusus Dilayani : Tidak ada

Nama Bank : BPD KALIMANTAN TE... 
Cabang KCP/Unit : BPD KALIMANTAN TENGAH CABANG KUMAI...

$\begin{array}{lll}\text { Rekening Atas Nama } & \\ \text { ASUNGAIKAPITAN... } & \end{array}$

SDNISUNGAIKAPITAN...

Luas Tanah Milik : 3

Luas Tanah Bukan Milik : 0

Status BOS : Bersedia Menerima

Waku Penyelenggaraan : Pagi

Sertifikasi ISO : Belum Bersertifikat

Sumber Listrik : PLN

Daya Listrik : 900

Akses Internet : Tidak Ada

\section{Waktu Penelitian}

Adapun waktu dan kegiatan penelitian ini di paparkan sebagai berikut:

Tabel I Waktu Dan Kegiatan Penelitian

\begin{tabular}{|l|l|}
\hline \multicolumn{1}{|c|}{ Bulan } & \multicolumn{1}{|c|}{ Kegiatan } \\
\hline September & $\begin{array}{l}\text { Mempersiapkan refrensi dan } \\
\text { bahan penelitian }\end{array}$ \\
\hline September & $\begin{array}{l}\text { Konsultasi dengan kepala } \\
\text { sekolah dan teman-teman guru, } \\
\text { Menyusun proposal }\end{array}$ \\
\hline Oktober & $\begin{array}{l}\text { Pelaksanaan Siklus I lanjut } \\
\text { analisis data }\end{array}$ \\
\hline Oktober & $\begin{array}{l}\text { Pelaksanaan Siklus II lanjut } \\
\text { analisis data }\end{array}$ \\
\hline November & Menambah refrensi penelitian \\
\hline November & Menyusun laporan penelitian \\
\hline
\end{tabular}

\section{B. Subjek Penelitian}

Adapun populasi penelitian ini adalah seluruh siswa SDN I Sungai Kapitan tahun ajaran 2019/2020, sedangkan sampel penelitian ini adalah siswa Kelas $V$ SDN I Sungai Kapitan. Berikut subjek penelitian ini:

Tabel 2 Sampel Penelitian

\begin{tabular}{|c|l|}
\hline NO & \\
\hline I & M. Gholam \\
\hline 2 & Marhadi \\
\hline 3 & Lulu Munawaroh \\
\hline 4 & Tiara Aprilia Putri Ningsih \\
\hline 5 & Siti Norhasanah \\
\hline 6 & Ahmad Juniyadi \\
\hline
\end{tabular}

\section{Sumber Data}

I. Data Primer

Data primer dalam penelitian ini di peroleh dari siswa (subjek penelitian melalui pengisian angket dan observasi.

2. Data Sekunder

Adapun data sekunder dalam penelitian ini adalah penilaian sikap siswa yang di peroleh dari hasil observasi.

\section{Alat dan Teknik Pengumpulan Data}

Teknik Pengumpulan data terdiri dari

I. Teknik Test

Tes merupakan salah satu cara Tes merupakan salah satu cara untuk
menaksirkan besarnya kemampuan seseoarng secaratidak langsung, yaitu melalui respons seseorang terhadap stimulus atau pertanyaan.

2. Teknik non test

Teknik non-tes diartikan sebagai sesuatu yang digunakan untuk mempermudah pihak-pihak tertentu untuk memperoleh kualitas atas suatu objek dengan menggunakan teknik non-tes.

Teknik non tes yang di lakukan dalam penelitian ini berupa:

\section{a. Observasi}

Observasi merupakan suatu proses pengamatan dan pencatatan secara sistematis, logis, objektif dan rasional mengenati berbagai fenomena yang bertujuan untuk mengumpulkan data atau informasi dan mengukur factor-faktor yang diamati khususnya kecakapan social.

\section{b. Wawancara}

Wawancara merupakan salah satu bentuk instrument evaluasi jenis non tes yang dilakukan melalui percakapan dan tanya jawab baik secara langsung tanpa alat perantara maupun secara tidak langsung.

c. Angket

Angket merupakan alat untuk mengumpulkandan mencatat data, informasi, pendapat, dan paham dalam hubungan kausal. Angket dapat dikelompokan benjadi beberapa kelompok.

Adapun alat pengumpulan data dalam penelitian ini adalah berupa:

I. Soal Test Siswa yang terdiri dari soal siklus I dan soal siklus II

2. Lembar observasi untuk mengungkap siapa saja siswa yang aktifitas belajarnya rendah.

3. Pedoman wawancara untuk mengungkap latar belakang kenapa aktifitas belajar siswa rendah khususnya pada materi tentang lbadah puasa ramadhan

4. Angket berupa draft pernyataan untuk mengungkap keberhasilah pembelajaran kooperatif berbantuan media gambar dalam meningkatkan aktifitas belajar siswa materi lbadah puasa ramadhan.

\section{HASIL PENELITIAN DAN PEMBAHASAN}

\section{A. Deskripsi Kondisi Awal}

Pada kondisi awal peneliti belum melaksanakan pembelajaran kooperatif berbantuan media gambar. Pada pra siklus peneliti mengamati aktifitas belajar siswa dan melakukan test tentang lbadah puasa ramadhan untuk mengetahui aktifitas belajar siswa sebelum peneliti menerapkan pembelajaran kooperatif berbantuan media gambar.

Berikut adalah hasil observasi peneliti terhadap aktifitas belajar siswa sebelum tindakan:

Tabel 3 Aktifitas Belajar Siswa Pra Siklus

\begin{tabular}{|c|c|c|c|c|c|c|c|c|c|c|c|c|c|}
\hline \multirow[t]{2}{*}{ ant } & \multirow[t]{2}{*}{ No } & \multirow[t]{2}{*}{ Nama } & \multirow{2}{*}{$\begin{array}{l}\mathrm{Al} \\
\mathrm{Y}\end{array}$} & \multicolumn{2}{|c|}{$\mathrm{A} 2$} & \multicolumn{3}{|c|}{ A3 } & \multicolumn{2}{|c|}{ A4 } & \multicolumn{2}{|c|}{ A5 } & \multirow{2}{*}{$\begin{array}{l}\text { Sko } \\
\text { r }\end{array}$} \\
\hline & & & & & & $\bar{Y}$ & & $\bar{T}$ & $\mathrm{Y}$ & 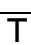 & & $\mathrm{T}$ & \\
\hline & $\mathrm{T}$ & M. Gholam & 1 & & & & & 0 & & 0 & & 0 & I \\
\hline & 2 & Marhadi & $\mathrm{I}$ & & & & & 0 & & 0 & & 0 & $\mathrm{~T}$ \\
\hline untuk & 3 & $\begin{array}{l}\text { Lulu } \\
\text { Munawaroh }\end{array}$ & 1 & & & & & 0 & & 0 & & 0 & $\mathrm{I}$ \\
\hline
\end{tabular}




\begin{tabular}{|c|l|c|c|c|c|c|c|c|c|c|c|c|}
\hline 4 & $\begin{array}{l}\text { Tiara Aprilia } \\
\text { Putri Ningsih }\end{array}$ & I & & & 0 & & 0 & & 0 & & 0 & 1 \\
\hline 5 & $\begin{array}{l}\text { Siti } \\
\text { Norhasanah }\end{array}$ & 1 & & & 0 & & 0 & & 0 & & 0 & \\
\hline 6 & $\begin{array}{l}\text { Ahmad } \\
\text { Juniyadi }\end{array}$ & 1 & & 0 & & 0 & & 0 & 1 & & \\
\hline
\end{tabular}

\section{Keterangan:}

Aspek I: Siswa mendengarkan materi yang di sampaikan guru

Aspek 2: Siswa terlihat antusias dalam mengikuti pembelajaran PAI materi lbadah puasa ramadhan

Aspek 3: Siswa dapat mengungkapkan pendapatnya

Aspek 4: Siswa bertanya tentang hal-hal yang tidak di ketahui

Aspek 5: Siswa dapat bekerja kelompok dengan teman lainnya

Keterangan:

Ya: I

Tidak: 0

Kriterian Nilai

Skor Maksimal Tiap siswa 5XI:5

Skor Maksimal semua siswa: 6X5: 30

Kriteria Nilai:

20-30: Aktifitas siswa di dalam kelas sangat baik

10-19: Aktifitas siswa di dalam kelas cukup baik

1-9: Aktifitas siswa di dalam kelas kurang baik

Pada pra siklus di hasilkan skor observasi 7 artinya Aktifitas siswa di dalam kelas kurang baik.

Selanjutnya peneliti merekap hasil nilai siswa pada pra siklus

Tabel 4 Nilai Siswa Pra Siklus

\begin{tabular}{|c|l|l|l|}
\hline NO & \multicolumn{1}{|c|}{ NAMA } & \multicolumn{1}{|c|}{ Nilai } & \multicolumn{1}{|c|}{ Keterangan } \\
\hline I & M. Gholam & 80 & Tuntas \\
\hline 2 & Marhadi & 60 & Tidak Tuntas \\
\hline 3 & Lulu Munawaroh & 60 & Tidak Tuntas \\
\hline 4 & Tiara Aprilia Putri Ningsih & 60 & Tidak Tuntas \\
\hline 5 & Siti Norhasanah & 60 & Tidak Tuntas \\
\hline 6 & Ahmad Juniyadi & 50 & Tidak Tuntas \\
\hline \multicolumn{2}{|l|}{ Nilai rata-rata } & 67,03 & \\
\hline Jumlah Siswa Tuntas Belajar & I & \\
\hline
\end{tabular}

Selanjutnya peneliti merasa begitu penting untuk melaksanakan penelitian dengan menggunakan metode pembelajaran kooperatif berbantuan media gambar.

\section{B. Deskripsi Siklus I}

a. Perencanaan

Pada siklus ini di lakukan sebanyak $2 X$ pertemuan untuk itu guru menyiapkan 2 Rencana Pelaksanaan Pembelajaran (RPP). Pada setiap pertemuan di siapkan lembar kerja peserta didik (LKP) dan soal tes, untuk mengambil data tentang aktifitas guru dan peserta didik peneliti menyiapkan lembar observasi guru dan peserta didik. b. Pelaksanaan Tindakan

Pada saat pelaksanaan tindakan guru melaksanakan proses pembelajaran mulai dari pembukaan dan sampai kegiatan ahir. Berikut adalah Zegiatan tindakan pada siklus I:

$\square$ Kegiatan Pendahuluan

7 a. Membuka pembelajaran dengan salam dan berdo'a bersama dipimpin oleh salah seorang peserta didik dengan penuh khidmat.

b. Memulai pembelajaran dengan membaca alQur'an surah pendek pilihan dengan lancar dan benar (nama surat sesuai dengan program pembiasaan yang ditentukan sebelumnya).

c. Memperlihatkan kesiapan diri dengan mengisi lembar kehadiran dan memeriksa kerapihan pakaian, posisi dan tempat duduk disesuaikan dengan kegiatan pembelajaran.

d. Mengajukan pertanyaan secara komunikatif berkaitan dengan materi pelajaran.

e. Menyampaikan kompetensi dasar dan tujuan yang akan dicapai.

f. Menyampaikan tahapan kegiatan yang meliputi kegiatan mencermati, menirukan, dan menyebutkan materi pelajaran dengan benar.

g. Mempersiapkan media/alat peraga/alat bantu bisa berupa tulisan di papan tulis/white board, gambar, jika memungkinkan melalui tayangan slide (media LCD projector).

\section{$\square$ Kegiatan Inti}

I) Pembelajaran diawali dengan pembacaan Q.S. al-Baqarah/2: 183 dan artinya secara klasikal.

2) Beberapa peserta didik mendemonstrasikan bacaan Q.S. al-Baqarah/2:183 dan artinya secara berpasangan.

3) Guru memberikan penguatan dengan nhenjelaskan kandungan Q.S. al-Baqarah/2: 183 tersebut.

I) Peserta didik mencermati ketentuan tentang puasa Ramadān sebagaimana terdapat dalam buku teks.

2) Guru dan peserta didik melakukan tanya jawab tentang puasa Ramadān. Guru menggali pengalaman peserta didik dengan mengajukan beberapa pertanyaan. Misalnya: "Siapa yang mengetahui makna Puasa Ramadān?”. Ayo tunjuk tangan! Jangan takut salah. Kalau tidak ada respon maka guru mengajak s swa membaca buku teks. Peserta didik membaca buku tek tentang puasa Ramadān.

3) Selanjutnya, guru mengajukan pertanyaan terkait materi yang ada pada buku teks. Misalnya: "Apa syarat dan rukun puasa Ramadān?".

4) Agar materi lebih dipahami, peserta didik dibagi ke dalam beberapa kelompok. Setiap kelompok mendiskusikan tentang ketentuan puasa Ramadān. Guru membuatkan panduan kerja. bawah ini.

Adapun langkah-langkah diskusi seperti di

- Masing-masing kelompok peserta didik menjaga ketertiban kelompoknya.

- Menunjuk ketua kelompok, dan berbagi tugas.

- Mencermati ketentuan puasa Ramadān yang terdapat di dalam buku teks. 
- Mendiskusikan bersama teman dalam satu kelompok tentang puasa Ramadān.

- Semua aktivitas dalam kelompok dicatat, seperti pendapat teman, kesepakatan, dan kesimpulan.

- Mengerjakan dengan sungguh-sungguh.

5) Berikutnya, mempresentasikan hasil diskusi dengan bimbingan. Setiap kelompok diikuti oleh semua anggotanya tampil dengan peran masing-masing. Sementara kelompok lain ikut mencermati dan menanyakan beberapa hal terkait dengan puasa Ramadān.

6) Guru memberikan penguatan terhadap paparan hasil diskusi yang ditampilkan oleh masingmasing kelompok.

$\square$ Kegiatan Penutup

I. Guru menyimpulkan dan meluruskan masalah-masalah yang dibahas.

2. Guru mengevaluasi sejauh mana pemahaman siswa.

3. Guru memberikan PR

4. Guru memberikan tugas membaca untuk materi selanjutnya.

5. Guru mengucapkan salam.

Berikut adalah hasil nilai siswa siklus I setelah mengikuti tes:

Tabel 5 Nilai Hasil Belajar Siswa Siklus I

\begin{tabular}{|c|l|l|l|}
\hline NO & \multicolumn{1}{|c|}{ NAMA } & \multicolumn{1}{|c|}{ Nilai } & \multicolumn{1}{|c|}{ Keterangan } \\
\hline I & M. Gholam & 80 & Tuntas \\
\hline 2 & Marhadi & 80 & Tuntas \\
\hline 3 & Lulu Munawaroh & 80 & Tuntas \\
\hline 4 & Tiara Aprilia Putri Ningsih & 70 & Tidak Tuntas \\
\hline 5 & Siti Norhasanah & 70 & Tidak Tuntas \\
\hline 6 & Ahmad Juniyadi & 60 & Tidak Tuntas \\
\hline $\begin{array}{l}\text { Nilai Rata-rata } \\
\text { Jumlah Siswa Tuntas Belajar }\end{array}$ & 77,22 & \\
\hline
\end{tabular}

\section{c. Observasi}

Tabel 6 Hasil Observasi Siswa Siklus I

\begin{tabular}{|c|c|c|c|c|c|c|c|c|c|c|c|c|}
\hline \multirow[t]{2}{*}{ No } & \multirow[t]{2}{*}{ Nama } & \multicolumn{2}{|c|}{$\mathrm{Al}$} & \multicolumn{2}{|c|}{$\mathrm{A} 2$} & \multicolumn{2}{|c|}{ A3 } & \multicolumn{2}{|c|}{ A4 } & \multicolumn{2}{|c|}{ A5 } & \multirow[t]{2}{*}{ Skor } \\
\hline & & $Y$ & $\mathrm{~T}$ & $\mathbf{Y}$ & $\mathrm{T}$ & $\mathbf{Y}$ & $\mathrm{T}$ & $\mathbf{Y}$ & $\mathrm{T}$ & $\bar{Y}$ & Tdk & \\
\hline $\mathrm{I}$ & M. Gholam & I & & $I$ & & & 0 & & 0 & I & & 3 \\
\hline 2 & Marhadi & I & & I & & & 0 & & 0 & I & & 3 \\
\hline 3 & $\begin{array}{l}\text { Lulu } \\
\text { Munawaroh }\end{array}$ & $\mathrm{I}$ & & $\mathrm{I}$ & & & 0 & & 0 & I & & 3 \\
\hline 4 & $\begin{array}{l}\text { Tiara Aprilia } \\
\text { Putri Ningsih }\end{array}$ & I & & $\mathrm{I}$ & & & 0 & & 0 & I & & 3 \\
\hline 5 & $\begin{array}{l}\text { Siti } \\
\text { Norhasanah }\end{array}$ & & 0 & & 0 & I & & $I$ & & I & & 3 \\
\hline 6 & $\begin{array}{l}\text { Ahmad } \\
\text { Juniyadi }\end{array}$ & $\mathrm{I}$ & & I & & I & & $I$ & & & 0 & 4 \\
\hline Juml & Skor & & & & & & & & & & & 19 \\
\hline
\end{tabular}

Keterangan:

Aspek I: Siswa mendengarkan materi yang di sampaikan guru

Aspek 2: Siswa terlihat antusias dalam mengikuti pembelajaran PAI materi Ibadah puasa ramadhan
Aspek 3: Siswa dapat mengungkapkan pendapatnya

Aspek 4: Siswa bertanya tentang hal-hal yang tidak di ketahui

Aspek 5: Siswa dapat bekerja kelompok dengan teman lainnya

Ya: I

Tidak: 0

Kriterian Nilai

Skor Maksimal Tiap siswa 5X1:5

Skor Maksimal semua siswa: 6 X5: 30

Kriteria Nilai:

20-30: Aktifitas siswa di dalam kelas sangat baik

10-19: Aktifitas siswa di dalam kelas cukup baik

I-9: Aktifitas siswa di dalam kelas kurang baik

\section{d. Refleksi}

Pada siklus I Jumlah Siswa Tuntas Belajar mencapai 3 siswa, nilai rata-rata mencapai 77,22 Artinya pembelajaran kooperatif berbantuan media gambar efektif di gunakan untuk meningkatkan aktifitas belajar siswa pada materi lbadah puasa ramadhan.

Pada kegiatan observasi peserta didik, guru menilai bahwa siswa mendengarkan materi yang di sampaikan guru, siswa terlihat antusias dalam mengikuti pembelajaran PAI materi lbadah puasa ramadhan, siswa dapat mengungkapkan pendapatnya, Siswa bertanya tentang hal-hal yang tidak di ketahui dan siswa dapat bekerja kelompok dengan teman läinnya.

Hasil observasi menunjukkan skor 19 Artinya Aktifitas siswa di dalam kelas cukup baik. Akan tetapi agar lebih kondusif lagi pembelajaran PAI materi Ibadah puasa ramadhan maka peneliti hendak melaksanakan slklus II.

\section{Pembahasan}

Tingkat keberhasilan suatu pendidikan adalah dilihat dari aktifitas belajar siswa yang telah kita ketahui melalui rapor. Sehingga menyebabkan yang dinamakan suatu urutan perolehan. Sehingga terlihat yang dinamakan prestasi dari belajar itu sendiri. Aktifitas belajar yang bagus memungkinkan seorang siswa bahwa dirinya adalah siswa yang berhasil dalam proses belajar tersebut.

Pada pra siklus Jumlah Siswa Tuntas Belajar hanya mencapai I siswa, nilai rata-rata hanya mencapai 67,03. Hasil observasi menunjukkan skor 7 Artinya Aktifitas siswa di dalam kelas kurang baik.

Pada siklus I Jumlah Siswa Tuntas Belajar mencapai 3 siswa, nilai rata-rata mencapai 77,22 Artinya pembelajaran kooperatif berbantuan media gambar efektif di gunakan untuk meningkatkan aktifitas belajar siswa pada materi lbadah puasa ramadhan.

Pada kegiatan observasi peserta didik, guru menilai bahwa siswa mendengarkan materi yang di sampaikan guru, siswa terlihat antusias dalam mengikuti pembelajaran PAI materi Ibadah puasa ramadhan, siswa dapat mengungkapkan pendapatnya, Siswa bertanya tentang hal-hal yang tidak di ketahui 
dan siswa dapat bekerja kelompok dengan teman lainnya.

Hasil observasi menunjukkan skor 19 Artinya Aktifitas siswa di dalam kelas cukup baik. Akan tetapi agar lebih kondusif lagi pembelajaran PAI materi lbadah puasa ramadhan maka peneliti hendak melaksanakan siklus II.

\section{E. Hasil Penelitian}

Pada pra siklus Jumlah Siswa Tuntas Belajar hanya mencapai I siswa, nilai rata-rata hanya mencapai 67,03. Hasil observasi menunjukkan skor 7 Artinya Aktifitas siswa di dalam kelas kurang baik.

Pada siklus I Jumlah Siswa Tuntas Belajar mencapai 3 siswa, nilai rata-rata mencapai 77,22 Artinya pembelajaran kooperatif berbantuan media gambar efektif di gunakan untuk meningkatkan aktifitas belajar siswa pada materi lbadah puasa ramadhan.

Pada kegiatan observasi peserta didik, guru menilai bahwa siswa mendengarkan materi yang di sampaikan guru, siswa terlihat antusias dalam mengikuti pembelajaran PAI materi lbadah puasa ramadhan, siswa dapat mengungkapkan pendapatnya, Siswa bertanya tentang hal-hal yang tidak di ketahui dan siswa dapat bekerja kelompok dengan teman lainnya.

Hasil observasi menunjukkan skor 19 Artinya Aktifitas siswa di dalam kelas cukup baik. Akan tetapi agar lebih kondusif lagi pembelajaran PAI materi lbadah puasa ramadhan maka peneliti hendak melaksanakan siklus II.

\section{PENUTUP}

\section{A. Kesimpulan}

Tingkat keberhasilan suatu pendidikan adalah dilihat dari aktifitas belajar siswa yang telah kita ketahui melalui rapor. Sehingga menyebabkan yang dinamakan suatu urutan perolehan. Sehingga terlihat yang dinamakan prestasi dari belajar itu sendiri. Aktifitas belajar yang bagus memungkinkan seorang siswa bahwa dirinya adalah siswa yang berhasil dalam proses belajar tersebut.

Pada pra siklus Jumlah Siswa Tuntas Belajar hanya mencapai I siswa, nilai rata-rata hanya mencapai 67,03. Hasil observasi menunjukkan skor 7 Artinya Aktifitas siswa di dalam kelas kurang baik.

Pada siklus I Jumlah Siswa Tuntas Belajar mencapai 3 siswa, nilai rata-rata mencapai 77,22 Artinya pembelajaran kooperatif berbantuan media gambar efektif di gunakan untuk meningkatkan aktifitas belajar siswa pada materi lbadah puasa ramadhan.

Pada kegiatan observasi peserta didik, guru menilai bahwa siswa mendengarkan materi yang di sampaikan guru, siswa terlihat antusias dalam mengikuti pembelajaran PAI materi lbadah puasa ramadhan, siswa dapat mengungkapkan pendapatnya, Siswa bertanya tentang hal-hal yang tidak di ketahui dan siswa dapat bekerja kelompok dengan teman lainnya.

Hasil observasi menunjukkan skor 19 Artinya Aktifitas siswa di dalam kelas cukup baik. Akan tetapi agar lebih kondusif lagi pembelajaran PAI materi lbadah puasa ramadhan maka peneliti hendak melaksanakan siklus II.

\section{B. Saran}

Dalam penelitian ini ada beberapa hal yang perlu mendapat perhatian yang merupakan saran peneliti kepada para pembaca umumnya, serta pihak- pihak yang berkepantingan, yaitu :

I. Pembelajaran kooperatif berbantuan media gambar dapat diterapkan pada kelas yang mempunyai karakteristik seperti kelas yang dijadikan subjek penelitian ini.

2. Hendaknya pembelajaran dengan Pembelajaran kooperatif berbantuan media gambar ini dicoba untuk diterapkan pada mata pelajaran yang lain.

\section{DAFTAR PUSTAKA}

Suprijono, Agus. 2006 . Cooperative Learning ( Teori \& Aplikasi PAIKEM).

Drs. Sugiyanto. Modul PLPG

Departemen Pendidikan dan Kebudayaan, Kamus Besar Bahasa Indonesia, Bandung : Balai Pustaka, 1990

http://guruPAl.wordpress.com/category/pembelajaran/ page/3/tanggal 13 juni 2015 Imam Nawawi, Terjemah Riyadhus Shalihin, Jakarta: Pustaka Amani, 1999

Iqbal Hasan, Analisis Data Penelitian Dengan Statistik, Jakarta: Bumi Aksara, 2004

Muhammad Ali, Strategi Penelitian Pendidikan Statistik Bandung, Bumi Aksara, 1993

Muhibbin Syah, Psikologi Pendidikan Dengan Pendekatan Baru, Bandung: Remaja Rosdakarya Offset, 2002

Nana Syaodih Sukmadinata, Metode Penelitian Pendidikan, Bandung : Remaja Rosda Karya, 2005

Hamalik Oemar, Pengertian Media Gambar, http://ian.wordpress. Compentingnya mediaprestasi-dalam-belajar, dalam 2014

Rahadi, Aristo. 2003. Media Pembelajaran. Jakarta: Dikjen Dikti Depdikbud.

Arief S. Sadiman, dkk, Media Pendidikan, Jakarta: Rajawali Press, 2010), h. 17-18

Syaiful Bahri, Strategi Belajar Mengajar, (Jakarta: Rineka Cipta, 2013) hal 128-130

R. Angkowo Kosasih, Optimalisasi Media Pembelajaran, (Jakarta: Grasindo, 2007)

Ramdhani, Muhammad Tri. "Manajemen Pengembangan Kurikulum 20I3 Berbasis Komputer di SMPN 6 Palangka Raya." Jurnal Sains Komputer dan Teknologi Informasi I.I (2018): II-I9. 